\title{
CONSIDERATIONS ON RECRUITING AND RETAINING UNIVERSITY TEACHERS
}

Gabriela MIHĂILĂ-LICĂ, Wiegand Helmut FLEISCHER**, Lucia PALEA*

\author{
*"Nicolae Bălcescu" Land Forces Academy, Sibiu, Romania \\ **“Lucian Blaga" University, Sibiu, Romania \\ mihailag2001@yahoo.com, wiegand.fleischer@gmail.com
}

\begin{abstract}
The university education in Romania is facing various challenges, from the pressure to reach a balance between teaching activities, research and services for the society, to little funds and a decrease of the interest of teachers with doctoral degrees in the teaching career. The quality of the learning the students receive is dependent on the quality of the teachers the university system employs. The right human resources for the right jobs means, in the long run, not only saving money, but also investing in the future of the Romanian society. The teachers working in the university system of education need to be not only highly skilled, but also extremely motivated. Our paper focuses on some of the things and changes that could be taken into account in order to retain and recruit the best teachers in whose training a lot of investments have already been made.
\end{abstract}

\section{Keywords: recruiting, retaining, university teachers}

\section{Introduction}

Since nowadays' society requires students to be able to confront a multitude of complex situations, the traditional education based solely on the transmission of knowledge is no longer sufficient. The students need to demonstrate the acquisition of skills and competences and to become "the managers of their own learning process". [1]

Cristina Leovaridis Şi Andreea Nicolăescu in their work entitled "Universităţile româneşti pe calea antreprenoriatului universitar" ("The Romanian Universities on the Way to University Entrepreneurship") state that the faculties have to prepare the students to be able to start their own businesses, to cooperate, to conduct innovative and research activities. The two aforementioned authors enumerate some of the innovative institutional changes they noticed: "the existence of laboratories and research centers; centers of technological transfer; consultancy centers; institutes createdaround the universities; partnerships with private companies; partnerships with public institutions; cooperation based on common projects; the involvement of students in research; sponsorships(funding) from outside(for example from businesses, foundations, etc.); the participation in international research networks; the involvement in the local development of the area in which the university is located, etc." [2]

1. 2. Criteria to be met by the candidates for university teaching positions

2. In order to provide students with high quality training and for directing the activities mentioned by Cristina Leovaridis and Andreea Nicolăescu, the universities must recruit graduate and postgraduate students that meet all the following requirements:

3. had very good results during their undergraduate and postgraduate studies;

4. they have shown interest and have successfully participated in student conferences; 
5. followed or are willing to attend the courses of the psycho-pedagogical module;

6. are interested in research;

7. intend to pursue a doctoral degree program;

8. have a penchant for the teaching activity, having excellent communication skills and the pleasure of working with young people, etc.;

9. they are fluent in one or more foreign languages of international circulation.

10. Present situation "For most experts, the quality of an education system is reflected by the quality of the human resources that the system has. Teachers are the only "variable" that has the ability to compensate for the socio-economic handicap of a pupil / student or for the poor conditions in which he/she teaches.'[3]

11. According to data presented by EUROSTAT (2012), our country is the EU member that allocates the least money per pupil/student. [4]

12. The quality and the motivation of the human resources working inthe academic field will, no doubt, bear a huge impact on the quality of the graduates that will become part of the labor force and this is an aspect that all policy makers should take into account. By investing in the right human resources, at the right time, the system of education and, implicitly the Romanian society will not only save money in the long run, but they will also be able to thrive.

13. We believe that the main investment in the human resources should be directed to the area of significant continuous training and developing of professional competences.

The negative demographic tendencies have strongly affected the Romanian education system. "The demographic projections are not optimistic, indicating a decrease in the number of pupils and students. "Only 465,000 students were enrolled in college in the last academic year, compared to
891,000 four years ago, at the onset of the economic crisis, according to a report of the NIS (National Institute of Statistics). The lack of jobs and the generations of graduate unemployed that have graduated from universities in recent years has led students to shift to post-secondary schools that allow for rapid qualifications and are well received by employers.

The decrease in the number of students is, of course, a consequence of the evolution of the birth rate during the last 20 years, but the NIS statistics also show a decrease of the young people's interest in Romania for higher education. In the school year $2012 / 2013$, only $55 \%$ of the young people aged 19 to 23 were attending a college, while in the school year 2008/2009, the degree of inclusion of the young people in this age group rose to $78 \%$." [5]

14. Due to the decrease in the number of students, there will be a decreasing number of vacancies. The teachers hired with continuous contract of employment, will most probably, have priority for a tenure. They will also represent the majority of the teachers the system will use for decades to come. Moreover, one has to take in to consideration the extended retirement age as teachers must remain in service for over 30 years.

15. Despite the reduction in the number of students and pupils, one has also noticed a decrease in the number of teachers. Thus, according to an article published in 2014, in Tribuna, which takes data of NIS, Romania lost in last 10 years nearly 30,000 teachers, shows statistics compiled by incont.ro, based on data provided by the National Institute of Statistics.[6]

16. One of the causes that contributed to the emergence of this phenomenon, says Ciprian Fartusnic, is, besides the very low salaries, the "steady erosion of the status and image of the teachers, a fact which has led to a decrease of those whose first option (not as a safety net job) is the teaching career". The same author, referring to the decreasing 
number of teachers, also focuses on the sinusoidal evolution of the decentralization policies in education and the insufficient individualized support for those who are at the beginning of their teaching career.[7]

17. The university teachers who give up or are thinking of giving up the university teaching career complain about their huge teaching and research load, the multitude and complexity of tasks they have to achieve. There are teachers who participate in different committees, are involved in research projects or projects of other types, have different administrative and managerial functions.

18. Another condition to be met by those who aspire to a university or research career is to obtain a doctoral degree in the field of the disciplines they will teach. In addition to the professional qualities and the enormous work done by those who aspire to such a title, most candidates have to pay high taxes and the duration of such a demarche is of three years in most cases.

19. Due to the value for society brought by the holders of a doctor's degree,"many countries have tried to radically increase the numbers of doctorates in recent years. [...] These policies have been very successful. The latest Education Indicators in Focus issue, based on data published in Education at a Glance 2014, notes that between 2000 and 2012 the graduation rate among doctoral students has increased by $60 \%$ on average across OECD countries." [8]

20. There are even countries such as Switzerland, Sweden and Germany that "have expanded doctoral programmes as part of their efforts to rapidly improve their relative position in the science and research fields and in global university rankings. They take the lead, with graduation rates of $3.3 \%, 2.8 \%$ and $2.7 \%$, respectively". [9]

21. Even though because of this increase in the number of holders of this high professional qualification and because of the economic crisis, the employment opportunities in the university education system are reduced, many countries, and Romania is one of them, "are trying to increase the return on the huge investments made in doctoral programmes, by offering more opportunities at the postdoctoral level. [...] Governments have developed policies to widen the scope of the doctoral degree, by including various skills sets useful for future employment in other parts of the public and private sectors, so that a doctorate does not prepare a student exclusively for a research career. More frequently now, $\mathrm{PhDs}$ leave universities and research institutions to join research labs in private companies, public administrations and non-research jobs in various organisations..

22. [...] On average across OECD countries, the employment rate for $\mathrm{PhDs}$ reaches $91 \%$, compared with $85 \%$ for bachelor's and master's degree holders. And, even more interesting, their employment rates in the private sector and government agencies are very significant in a number of countries. Society at large increasingly benefits from the research skills and experience that these people have acquired." [10]

23. We believe that the most important measure of the ones we would like to see implemented with regard to the recruiting of the teachers who will contribute to the forming of the students is the greater weight given to the marks obtained by them in the psychopedagogical module/master and in the tests that evidence their practical skills and to the teaching experience. The negative demographic trends will also have a positive aspect by providing an opportunity for the future selection of candidates to be more rigorous.

24. 4. Possible measures

Considering that the recruitment of the academic staff is done by choosing from the category of graduates with the best results 
during their undergraduate and graduate studies, the universities find themselves in a competitive situation with other potential employers with tempting offers. These competitors are businesses, research centers, public institutions, etc.

In order to attract and keep/retain the best young academics, universities must offer them the following conditions:

1. a pleasant working environment;

2. favorable possibilities for career development (tutorials provided by the experienced university teachers for the young academics in order to guide them both in terms of the didactic activity as well as in that of research; establishing a career plan and transparent criteria for promotion; offering the possibility to participate in training courses and internships in the country and abroad, etc.);

3. involvement in research projects. Being part of a project team or even of several project teams, the young teaching staff will feel better integrated in the collective and will also benefit from an additional source of funding that will make their personal incomes grow;

4. encouraging the young university teachers to take responsibility for organizing different events or academic activities (student scientific communications sessions, scientific 26. conferences, cultural events, sports activities, etc .;

5. In order to accumulate the necessary practical experience, but also to enrich their revenue, we recommend granting young university teacher the possibility to carry out complementary professional activities in the business environment, public institutions, research centers, etc.

\section{Conclusions}

In conclusion, we need a "coherent research strategy, a policy focused on quality assurance in research and research excellence, a climate that fosters innovation in research, a strategy for the recruitment and retention of valuable human capital, an efficient allocation of resources for the development of the research infrastructure, and the transferability and valorization of the research results. [...] A more effective and efficient system of recruitment implemented over five or ten years will have fewer opportunities to significantly change the quality of the teaching staff, simply because it will be applied to a smaller number of potential future teachers compared to the present situation".[11]

The attraction and keeping / retention of the best young university teachers is especially important for securing the future of higher education, but it is also one of the fundamental investments in the Romanian society.

25.

\section{References}

[1] Secu (Ştefan) Mihaela Aurelia, Dezvoltarea competenţei de învăţare autonomă la studenţi (teză de doctorat), http://www.unibuc.ro/studies/Doctorate2011Noiembrie/Secu\%20Mihaela\%20Aurelia\% 20-\%20Dezvoltarea $\% 20$ competentei $\% 20$ de $\% 20$ invatare $\% 20$ autonoma $\% 201 \mathrm{a} \%$ 20studenti/REZUMAT_TEZA_\%20DOCTORAT_SECU(STEFAN)_MIHAELA.pdf (22.03.2015).

[2] http://www.revistadesociologie.ro/pdf-uri/nr.5-6-2008/Leovaridis.pdf (27.05.2014).

[3] Fartunsic, Ciprian, Analiza politicilor de recrutare de personal pentru sistemul preuniversitar de invăţământ, http://www.crpe.ro/wp-content/uploads/2013/08/ Recrutare-personal-pentru-Preuniversitar-CRPE.pdf (23.02.2015).

[4] Idem

[5] http://adevarul.ro/educatie/universitar/raport-universitati-falimentare-numarulstudentilor-romania-scazut-jumatate-ultimii-patru-ani1_54d793dd448e03c0fd677644/index.html, 15.04.2015 
[6] Mai puţini elevi, mai puţini profesori, http://www.tribuna.ro/stiri/actualitate/mai-putinielevi-mai-putini-profesori-95953.html, 15.04.2015

[7] Fartunsic, Ciprian, Analiza politicilor de recrutare de personal pentru sistemul preuniversitar de învăţămân, http://www.crpe.ro/wp-content/uploads/2013/08/Recrutare -personal-pentru-Preuniversitar-CRPE.pdf (23.02.2015)

[8] Van Damme, Dirk, Doctorate degree holders take research skills outside academia, http://oecdeducationtoday.blogspot.ro/2014/10/doctorate-degree-holders-takeresearch.html (23.-3.2015)

[9] Idem

[10] Ibidem

[11] Fartunsic, Ciprian, Analiza politicilor de recrutare de personal pentru sistemul preuniversitar de învăţământ, http://www.crpe.ro/wpcontent/uploads/2013/08/Recrutare-personal-pentru-Preuniversitar-CRPE.pdf (23.02.2015)

27. 